\title{
Human Rights Protection in Albania
}

\author{
Erjon Hitaj \\ PhD in "Ordine Internazionale e Diritti Umani", Facoltà di Scienze Politiche, \\ Sociologia e Comunicazione, "Sapienza", Università di Roma
}

\section{Doi:10.5901/ajis.2015.v4n3s1p179}

\section{Introduction: Consideration Over the Current Albanian Constitution}

The current Albanian Constitution was approved and entered into force in $1998^{1}$, since a precedent attempt of constitutional referendum was rejected by the majority of people in 1994. The Albanian constituent Assembly, assisted by experts provided by the Council of Europe, for what concerns the question of the relationship between international and internal law has tried to be as clear as possible. In particular, in the first part of the Constitution regarding the basic principles of the Albanian legal system, the validity of general international law is recognized in direct and automatic way ${ }^{2}$. According to this «solution», the international law binding upon the State is composed, besides internationally recognized general rules (principles and customs), even by treaty law. If, at first sight, this equalization between treaty norms and International general norms (principles and customs) could bring to any apparent confusion, in truth it should be interpreted as a clear and precise choice of the Constitutional legislator in order to guarantee a greater protection extending, exactly, even to the treaty obligations the same Constitutional protection granted to the general international law. This «equality» of strengthened Constitutional treatment should not be realized as an attempt of equalization of international treaty law with general international law (considering that hardly could be reached this goal by mean of internal legislative techniques or methods); instead, it should be seen as a further corollary guarantee that the constituent decided to grant to international treaty law binding upon the State.

Anyway, considerable part of the Albanian doctrine influenced by «kelsenian` pure normativism sustains that the dictation of art. 5 of the Albanian Constitution is to be interpreted in a sense that it should include not only international treaty law, but also general accepted rules of international law, customs and principles (sic!) ${ }^{3}$; inevitably a basic objection emerges. It concerns the conception this doctrine has in regard with the nature of international law itself, as it considers international treaty law the milestone of international law without giving proper importance and place to general international law (principles and customs) 4 . Apart the glaring doctrinaire and methodic confusion of this position inasmuch

\footnotetext{
${ }^{1}$ The current Constitution of the Republic of Albania, approved by Constitutional law No. 8417 of 21/10/1998 subject to popular referendum on 22 November of the same year, entered into force on 28/11/1998, the day it received the promulgation of the President of the Republic. From its entry into force, this Constitution was amended two times, respectively on 13/01/2007 by Law No. 9675 and on 21/04/2008 by Law No. 9904. The fundamental act of the Republic of Albania enumerates 177 operative articles and six articles concerning transitory and final dispositions.

${ }^{2}$ Art. 5 of the Albanian Constitution: «The Republic of Albania applies international law that is binding upon it».

${ }^{3}$ "[...] në nocionin e të "drejtës ndërkombëtare të detyrueshme" për një shtet, do të ishin jo vetëm normat e traktateve apo të marrëveshjeve ndërkombëtare të ratifikuara shprehimisht nga ky shtet, por edhe normat përgjithësisht të pranuara të së drejtës ndërkombëtare zakonore, si dhe parimet e përgjithshme të së drejtës ndërkombëtare»; English translation: «under the notion "binding international law" upon a State fall, not only international treaty law, but even generally accepted customary law as well as general international principles», [Zaganjori, Vendi i së drejtës ndërkombëtare ne Kushtetutën e Republikës së Shqipërisë (The Rank of International Law in the Albanian Constitution), in Jeta Juridike, no. 2, 2004, p. 30]. Of the same opinion, Omari-Anastasi, E drejta ushtetuese (Constitutional Law), Tirana, 2010, p. 56.

${ }^{4}$ In fact, according to these Authors international law is mostly, if not exclusively, composed by International treaty law. So the relation between international law and internal law is conditioned only by the rank the Constitution reserves to duly ratified international treaties(!): «Në tërësi Kushtetuta e ka zgjidhur në mënyrë të detajuar (pjesa VII) problemin e raportit, duke përcaktuar hierarkinë midis normave, procedurat e ndërfutjes së normave ndërkombëtare në rendin juridik të brendshëm, si dhe kompetencat e organeve përkatëse në këtë fushë. Marrëveshjet ndërkombëtare të ratifikuara zënë vendin e dytë pas kushtetutës dhe marrin fuqi mbiligjore (neni $116 i$ Kushtetutës). Duket se Kushtetuta nuk e ka lëshuar vendin e parë dhe ruan superioritetin e vet mbi të gjitha aktet e tjera normative, pra edhe mbi marrëveshjet ndërkombëtare që ratifikohen me ligj (neni 116)»; English translation: «In general, the Constitution offers a
} 
as it relegates principles of international law at the same degree of custom and treaty law, emerges in this case even an interpretative incoherence with regard to the Constitutional provisions under exam.

International treaties in particular, as well as conventional International law in general, bind the signatory Part because a formal principle of International law (that originates from the auctoritas of the International community) exactly, the pacta sunt sevanda principle - prescribes this juridical effect ${ }^{5}$. For these reason, the ratio of this presumable «equalization» between primary and secondary norms of international law within art. 5 of the Constitution should be interpreted as a clear intention of the constituent to extend to duly ratified treaties the same constitutional guarantees; that does not imply any substantial equalization of these norms ${ }^{6}$. International treaties, as any other international instrument subject to ratification, «become part» of the (Albanian) domestic law only as a consequence of completion of internal procedures of ratification, properly sanctioned in the Constitution; the act of ratifications has only a subconstitutional rank (art. 116, § 1, Const.) ${ }^{7}$. Constitutional, in this case, is only the principle binding upon the State with regard to proper international obligations; that is nothing else but the tout court «internalization» of the pacta sunt servanda principle. According to the Constitution, International treaties, duly ratified, «become part» of the Albanian legal system and, in the hierarchy of the sources, occupy an «intermediate» position between Constitution and ordinary law of the State ${ }^{8}$.

c) At this point, a particular attention should be granted to the question of the collocation of human rights law in the constitutional framework. The communist model of the so-called «popular democracy», in force in Albania before the Nineties, used to consider the respect and guarantee of human rights direct and natural consequence of the social and economic equality of the citizens. This equality should have been reached only after the transformation of the economic bourgeois relationships in economic socialist ones, with no class conflict that produces oppressors and oppressed; all would have implied the real equality of the citizens. Only with the elimination of the social and economic inequality distinguishing element of the capitalist society, according to Marxism - highest human rights guarantee and protection standards could have been reached.

To be more precise, fundamental rights and liberties, though being formally sanctioned in the Constitution, were strictly conditioned on the economic relationships of the communist society; they were the superstructural reflection of (socialist) production relations. As long as the relations between individuals were not characterized by the class conflict dialectics (between bourgeois and proletarians, to be clear) even individual rights - considered, exactly, a superstructure - would have been the reflection of this relations and would have not been affected by any inequality.

The institute of human rights and its relative guaranties, as an integral part of the socialist public order, according to this theory, concurs to the indisputable goal of the socialism: «the progressive development of the popular democracy and the satisfaction of all the material and cultural needs of the workers ${ }^{9}$ (intended the latter as the unique ruling class in the socialist society). This kind of juridical relativism ${ }^{10}$, contrarily of what emerges in bourgeois occidental societies,

detailed solution [Part VII] of the question of the relation [between international and internal law], determining a clear hierarchy between norms, the procedures of adoption of international law in the internal juridical order and the competencies of respective institutions involved. International treaties, duly ratified, occupy the second rank after the Constitution and assume intermediate force [art. 116 Const.]. The Constitution holds the supremacy over all legislative acts, duly ratified international treaties included [art. 116]», (OmariAnastasi, E drejta., cit., p. 55).

${ }^{5}$ «Se la consuetudine e l'accordo costituiscono dei procedimenti di produzione giuridica internazionale, ciò è dovuto esclusivamente al fatto che due principi, il principio consuetudo est servanda e quello pacta sunt servanda, vedono tali procedimenti idonei a creare diritto», (Quadri, Diritto internazionale pubblico, Napoli, 1968, p. 109). For further consultation see even Sinagra-Bargiacchi, op. cit., pp. 105-142.

${ }^{6}$ Krisafi, Kushtetuta shqiptare dhe e drejta ndërkombetare (Albanian Constitution and International Law), in "5 vjet Kushtetutë", Tirana, 2004, pp. 100-111.

7 In fact, art 4, § 2 of the Constitution states that the: "The Constitution is the highest law in the Republic of Albania» and that international treaties, duly ratified, prevail over ordinary legislation but not over the Constitution itself. «An international agreement that has been ratified by law has superiority over laws of the country that are not compatible with it», (art. 122, § 2).

${ }^{8}$ Art. 116 of the Constitution: «1. Normative acts that are effective in the entire territory of the Republic of Albania are: a) the Constitution; b) ratified international agreements; c) the laws; d) normative acts of the Council of Ministers».

${ }^{9}$ Dhima, E drejta kushtetuese e Republikës popullore te Shqipërisë (The Constituional Law of the People's Republic of Albania), Tirana, 1963, p. 144.

10 "La norma giuridica si pone come la espressione del regime socio-politico che è la risultanza delle relazioni economiche condizionate dalle forze di produzione cosi come disciplinate ed organizzate nello Stato socialista. Più direttamente, dunque, in questo il diritto si risolve nella politica, a differenza della concezione occidentale dove si tende a risolvere la politica nel diritto. ... Ciò significa che la 
originates from the very basis of the socialist systems, inasmuch the norms concerning human rights protection are traditionally conditioned on the principle of the safeguard of the public order and the development of the socialist State ${ }^{11}$.

Diametrically different is the new constitutional framework of the «occidental» Albania. The human rights had to be the inspiring principle of the democratic society ${ }^{12}$. The whole social, economic and legislative framework of the Country could not prescind from that essential and fundamental core of individual rights and liberties that characterizes the occidental model of society. So, in the same Constitution of 1998, was sanctioned in a clear and unequivocal way the compliance with the fundamental principles of the International community in the field of human rights ${ }^{13}$.

For what regards the rank that International human rights law occupies in the Albanian Constitution, the constituent, even on International experts recommendation, demonstrated particular attention and sensibility towards the European system of human rights protection. European Convention on Human Rights (echr) ${ }^{14}$ became part of the constitutional provisions binding, in a direct and indisputable way, the legislative activity of the Parliament, particularly with regard to (potential) limitations of human rights in peremptory hypothesis of public interest and protection of rights of others ${ }^{15}$. Direct consequence of this mechanism is the exclusive competence of the constitutional judge to question the compatibility of the limitations in object with what permitted by echr, also in the light of the interpretations of the Court of Strasbourg ${ }^{16}$. Any failure to respect the European minimum standards, in this case, would be considered a violation of art. 17 of the Constitution and thus declared unconstitutional by the (Constitutional) Court ${ }^{17}$. The constitutional placement of echr, although in «negative» terms of prohibition of limitations if violable of those permitted in the European system, represents an absolute originality for the human rights cause. In case the Parliament decided to restrict the core of human rights and liberties beyond limitations permitted by echr, the constitutional mechanism represents the perfect instrument in the hands of the guardian of the Constitution - the Constitutional Court - to invalidate, in legal ways, attempts of this kind.

Actually, the value of echr in the Albanian legal system has a double dimension: on one hand the Convention guarantees at constitutional rank the minimal core of human rights as provided for at European level placing an insuperable limit to any attempt of human rights restriction within the hole legal system; on the other hand, as sanctioned also in the art. 116 of the Constitution, the echr inasmuch as international agreement ratified by Parliament's law, assumes a pre-constitutional rank within the Albanian legal system and, thus, prevails on any contrary ordinary law ${ }^{18}$. In this case, echr assumes the role of an intermediate constitutional norm in the sense that it becomes a constitutional reference parameter for the ordinary legislation in case of possible contrast. It depends on Constitutional Court to decide, if requested, over the compatibility of ordinary laws with echr according to art. 116 and 131 of the Constitution and,

norma è priva di valore assoluto, ma si pone dialetticamente in termini relativistici» (Sinagra, II principio di legalità socialista negli ordinamenti giuridici degli Stati a democrazia popolare, in Rivista internazionale di filosofia politica e sociale e di diritto comparato, Bologna, 1975, Fasc. 1/4, p. 78).

${ }_{11}$ Emblematic in this case art. 39 of the Constitution of 1976: "The rights and duties of citizens are built on the basis of the reconciliation of the interests of the individual and the socialist society, giving priority to the general interest. The rights of the citizens are inseparable from the fulfillment of their duties and cannot be exercised in opposition to the socialist order. The further extension and deepening of the rights of citizens are closely linked with the socialist development of the country».

12 Art. 15 of the current Constitution of 1998: «1. The fundamental human rights and freedoms are indivisible, inalienable, and inviolable and stand at the basis of the entire juridical order. 2. The organs of public power, in fulfillment of their duties, shall respect the fundamental rights and freedoms, as well as contribute to their realization».

13 "The independence of the state and the integrity of its territory, dignity of the individual, human rights and freedoms, social justice, constitutional order, pluralism, national identity and inheritance, religious coexistence, as well as coexistence with, and understanding of Albanians for, minorities are the bases of this state, which has the duty of respecting and protecting them», art. 3 of the Constitution.

${ }^{14}$ Albania joined the Council of Europe on 13 July 1995 while ECHR entered into force on 2 October 1996.

15 «1. The limitation of the rights and freedoms provided for in this Constitution may be established only by law for a public interest or for the protection of the rights of others. A limitation shall be in proportion with the situation that has dictated it. 2. These limitations may not infringe the essence of the rights and freedoms and in no case may exceed the limitations provided for in the European Convention on Human Rights»: art. 17 of the Constitution.

16 See, in Albanian language, also Sadushi, Jurisprudenca e Gjykatës Kushtetuese në frymën e Konventës Europiane për të Drejtat e Njeriut (Constitutional Court's jurisprudence in the light of ECHR), in E drejta parlamentare dhe politikat ligjore, No. XI, Tirana, 2003, p. 28-42.

${ }^{17}$ Art. 131 of the Constitution: " The Constitutional Court decides on: a) compatibility of the law with the Constitution or with international agreements as provided in article 122 [...]»; art. 132: «1. The decisions of the Constitutional Court have general binding force and are final. The Constitutional Court only has the right to invalidate the acts it reviews».

${ }^{18}$ See art. 122, § 2 of the Constitution. 
eventually, to declare their illegitimacy.

The same constitutional guarantee is extended to all international agreements in the field of human rights (and not only) given that the Constitution (art. 122, § 2) expressively provides for the prevalence of any duly ratified international agreement on ordinary law. Fall within this category the un Covenants on human rights of $1966^{19}$ as well as all those international and regional instruments ratified by Albania in the human rights field ${ }^{20}$.

\section{Democratic Standards and Human Rights}

The change of the precedent political system towards the occidental model of society at the principle of the Nineties inevitably brought to the complete replacement of the old economic, social and legislative infrastructure of the Country. The result of this profound opening towards a liberal democratic society had to bring to radical transformations in the human rights conception. Starting from the Constitution of the 1998, the whole legislative activity of the rising democracy faced with the human rights question. It was not a question of producing (and introducing) à la carte, any human rights and liberties catalogue as already recognized and protected in other developed Countries; it had to do with the construction of the fundaments of a democratic society, guarantor of individual and collective human rights in a period when the heritage of the dark past publically and jealously challenged the embryonic democracy. In a country where human rights for almost fifty years have had an precarious and sometimes inexistent status, the sudden transformation used to request the demolition of the past totalitarian legislative structure.

Although any Constitution was not adopted immediately, at the beginning of the Nineties important goals were achieved. Though brief and provisional, the «Constitutional Chart» of $1991^{21}$ sanctioned, for the first time at constitutional level, the defense and the fundamental guaranties in the human rights field22. The modest constitutional framework recognized, in the section dedicated to general provisions, the essential rights of the people under a perspective of equality of the citizens in front of the law ${ }^{23}$.

An important bill of rights issued on 1993 completed the provisional constitutional mosaic ${ }^{24}$. It was a catalogue of fundamental rights and liberties that sanctioned, for the first time in the Albanian legal system, the centrality and the dignity of the individual, rendering him a milestone of the whole society. Human rights and liberties, as sanctioned in all democratic Constitutions and guaranteed and protected in international Covenants, this time entered from the principal gate of the Albanian juridical order ${ }^{25}$. In addition, in accordance with the provisional Constitution, a criminal and procedure criminal code were approved ${ }^{26}$.

In practice, however, several problems related to the implementation of the human rights legislation framework emerged. As underlined even in non-governmental international organization's reports, during the first years of the

\footnotetext{
19 International Covenant on Civil and Political Rights, adopted and opened for signature, ratification and accession by General Assembly resolution 2200A (XXI) of 16 December 1966, entry into force 23 March 1976; International Covenant on Economic, Social and Cultural Rights, adopted and opened for signature, ratification and accession by General Assembly resolution $2200 \mathrm{~A}$ (XXI) of 16 December 1966, entry into force 3 January 1976. Albania ratified both instruments in 1991.

20 For a complete consultation of all international and regional treaties regarding human rights subscribed by Albania visit: http://www.mfa.gov.al/.

21 The provisional Constitution of 1991 was composed of only 46 articles concerning essential and temporary functioning of juridical and social order of the country.

${ }_{22}$ Article 2 [Foundations] «(1) The Republic of Albania is a juridical and democratic state. (2) Man's dignity, his rights and freedoms, free development of his personality as well as the constitutional order, equality before the law, social justice, and pluralism are the foundations of this state, whose duty is to observe and defend them». Article 4 [Human Rights, Minorities]: "The Republic of Albania recognizes and guarantees the fundamental human rights and freedoms, those of national minorities, admitted in the international documents».

${ }^{23}$ See art. 6 to 14 of the provisional Constitution.

${ }^{24}$ (Constitutional) Law No. 7692 of 31 March 1993 on amendments to law No. 7491 of 29 April 1991 (Constitutional provisions).

25 In particular, the bill of rights enumerated, ex multis, the right to life (art. 1), the freedom of thought and speech (art. 2), the absolute prohibition of torture and forced labour (art. 3 and 4), the inviolability of private liberty (art. 5), nulla poena sine lege principle (art. 6), the principle of presumption of innocence (art. 7), the right to a fair trial (art. 8), ne bis in idem principle (art. 12), the freedom of religion and conscience (art. 18), right to private property (art. 27), inviolable rights of minorities (art. 26), right to family life (art. 32-33) etc.. In other words, a catalogue of constitutionally protected rights, in full accordance with international and comparative standards of the time.

${ }^{26}$ Law No. 7895 of 27 January 1995: Criminal Code of the Republic of Albania; Law No. 7905 of 21 March 1995: Code of Criminal Procedure of the Republic of Albania.
} 
Albanian transition the capacity of the Albanian society to guarantee the full enjoyment of human rights and liberties was seriously questioned ${ }^{27}$. The one-party mentality inherited by the old regime and the non independence of judiciary power from the executive and political one jeopardized the human rights cause ${ }^{28}$. During this embryonic period cases of violence exercised by police forces against individuals, restrictions of individual liberties as those of media, association and manifestation were registered ${ }^{29}$.

Anyway, steps forward with regard to political and civil rights as well as to economic and social rights are not to be ignored. The free enterprise was guaranteed at all levels without any distinction while the old-style economy of the country gradually transformed into a capitalistic model.

But, following irregularities registered during the 1996 political elections, Albania faced the most serious institutional and political crisis of its transition ${ }^{30}$. The first step towards the general stabilization was the adoption of the 1998's Constitution.

With the adoption of this Constitution, followed by the general stabilization of the political situation, the legislative framework regarding human rights and liberties continued to improve. The new democratic Constitution endorsed the most important principles relating human rights and raised them to constitutional rank; (individual and collective) human rights and liberties finally lied in their natural habitat ${ }^{31}$. This constitutional catalogue does not only jealously safeguard the centrality of human rights in the Albanian legal culture but also aims to eradicate those archaic notions inherited from the old communist mentality according to which the unconditioned protection of human rights threatens the discretion of public institutions and challenges the State sovereignty ${ }^{32}$. The centrality and indefeasibility of human rights and dignity ${ }^{33}$, instead, are the milestone of the new legal order imposing to all organs of the State their full and unconditioned

${ }_{27}$ See at this regard a detailed report of Human Rights Watch Human Rights in Post-Communist Albania (1 March 1996).

${ }_{28}$ "Of particular concern is the state's continued interference in the judiciary. Despite many improvements, the court system is still used as an instrument of the state, especially against the political opposition. The leader of the largest opposition party is currently in prison after a trial fraught with due process violations. Since 1992, numerous other critics of the government have been harassed, tried, imprisoned or, in a few cases, physically attacked by unknown assailants usually without any response from the government. Judges who make independent decisions on sensitive cases are sometimes reassigned to lesser posts or fired. More than 400 persons, predominantly selected by the Democratic Party, were appointed as judges and prosecutors throughout the country, upon completion of a special six-month law course, thereby strengthening governmental influence over the judiciary and law enforcement officials», (Ibid., § 5).

${ }^{29}$ Very particular was the situation of the independent electronic media, where still in 1996 did not exist any organic law on private radio television. As widely demonstrated: "Freedom of the press is also circumscribed. No legislation exists to allow for the transmission of private television or radio, leaving the state-run programs that favor the government as the sole provider of news for the majority of the population. While there are many private newspapers throughout the country, they are restricted by a repressive press law and obstacles to their distribution. Since 1992, a large number of journalists, including foreign correspondents, have been harassed, arrested or beaten by unknown assailants after writing articles that were critical of the government», (Ibid, § 8).

${ }_{30}$ During 1997, in fact, Albania crossed the most serious institutional crisis of its transition. The right-handed ruling government was accused by the socialist opposition of poll-rigging during the political elections of May 1996; there followed worldwide protests among the country. In addition, because of the bankrupt of some investment funds which had collected considerable part of the citizen's savings, by the end of 1996 and the principle of 1997, especially in the South, the situation became particularly grave. The enormous intensity of the protests, provoked even by the complicity of the opposition of the time, overcame the government's intransigence; the natural consequence of that was the total collapse of public power and institutions in general. The events of 1997 widely demonstrated the weakness of the democratic institutions and the frailty of a transition towards a rule of law that hard put to arrive. For further deepening of the question of the Albanian transition see Vickers-Pettifer, Albania: From Anarchy to a Balkan Identity, New York, 1997; de GuttryPagani (ed), La crisi albanese del 1997, Milano, 1999; Bogdani-Loughlin, Albania and the European Union. The Tumultuous Journey towards Integration and Accession, London, New York, 2007; Kaltsounis, The Democratization of Albania. Democracy from Within, New York, 2010.

31 The current Constitution of 1998 dedicates a whole third part to the question of human rights, duly subdivided into six chapters, respectively concerning: I) General Principles; II) Personal Rights and Freedoms; III) Political Rights and Freedoms; IV) Economic, Social and Cultural Rights and Freedoms; V) Social Objectives; VI) Peoples Advocate.

32 See, for more details, Dhima, E drejta., cit., p. 141-163.

${ }^{33}$ "[...] ne Kushtetuten e Shqiperise, ne dallim nga formulime te tjera ne disa kushtetuta te vendeve demokratike, i eshte dhene dinjitetit te Njeriut, vendi i qarte i parimit themelor kushtetues. Ai sherben si nje baze themelore per te interpretuar te gjitha pjeset e Kushtetutes dhe respektimi e mbrojtja e tij, qendron ne themel te te gjithe rendit juridik»; English translation: "To the Men's dignity, in the Albanian Constitution, unlike similar dispositions of other democratic Constitutions, is reserved a clear status as fundamental constitutional principle. It serves as a fundamental reference for the interpretation of the rest of the Constitution's dispositions and its respect and protection is the milestone of the whole juridical order», [Omari-Anastasi, E drejta kushtetuese (The Constitutional Law), Tirana, 2010, p. 69]. 
implementation ${ }^{34}$.

A further fundamental element of the human rights protection system is certainly represented by the art. 17 of the Constitution ${ }^{35}$. From its analyze clearly emerge the peremptory hypothesis of human rights and liberties restriction: public interest and protection of rights of others; all in full and rigorous respect of the proportionality of the action and, most of all, only by the mean of a law of the Parliament. Furthermore, in any case, these restrictions or limitations shall never exceed those provided for in the echr. In this sense, the Constitutional Court, in a verdict of 2006, literally interpreting the article in question, firmly rejected the possibility of the Council of Ministers to intervene with proper acts (so-called normative acts) aiming the restriction or limitation of fundamental human rights and liberties stating that only the Parliament is the competent organ to legislate in similar cases ${ }^{36}$.

\section{The Role of the ECHR and National Institutions in the Implementation of Human Rights Dispositions}

A fundamental contribution in favor of the cause of human rights is given certainly by the institutions and organs provided for in the internal legal system. They are the principal actors invested with the arduous task of converting legal dispositions in concrete actions. In this sense, important organs as Constitutional Court, People's Advocate, judiciary power as well as all the organs of public administration are some of the most clear examples. It is also to be underlined the contribution given by the non-governmental organizations, international and not, inasmuch as defenders and sustainers of requests coming from the social base. In many cases they are bearers of experiences of exemplar social battles as those regarding death penalty, environmental rights, bioethics, rights of categories of emarginated persons, rights of women, of children as well as those in case of humanitarian crisis. The mosaic of the involved actors would not be complete without mentioning the undisputable role of the European Court of Human Rights (Court of Strasbourg) whose contribution to the cause of human rights in the Albanian society is (and has been) of fundamental incidence. If steps forward have been made in the field in question (which in certain aspects are indisputable), it is because of the joint distribution and coordination of the responsibilities among these same actors, serious interlocutors between public power and social base.

In this context, the Constitutional Court, in full and rigorous respect of its competences, left an indelible mark in favor of human rights cause. Considering echr (as well as the Constitution) a strong reference point, the Constitutional Court intervention has given further clarity to the core of human rights compelling even the legislator to take concrete legislative initiatives in order to render internal legislation compatible with echr ${ }^{37}$.

In other occasions, the Court has gone beyond the spirit of Rome Convention itself and its interpretations given by

${ }^{34}$ Art. 3 of the Constitution: "The independence of the state and the integrity of its territory, dignity of the individual, human rights and freedoms, social justice, constitutional order, pluralism, national identity and inheritance, religious coexistence, as well as coexistence with, and understanding of Albanians for, minorities are the bases of this state, which has the duty of respecting and protecting them».

${ }^{35}$ Art. 17 of the Constitution: "1. The limitation of the rights and freedoms provided for in this Constitution may be established only by law for a public interest or for the protection of the rights of others. A limitation shall be in proportion with the situation that has dictated it. 2. These limitations may not infringe the essence of the rights and freedoms and in no case may exceed the limitations provided for in the European Convention on Human Rights».

${ }^{36}$ Constitutional Court of Republic of Albania, Court Verdict. n. 20, Albanian Helsinki Committee et. Others v. Council of Ministers, 11.07. 2006. In this verdict the Court declared the non-compatibility with the Constitution of three normative acts issued by the Council of Ministers, respectively no. 43, 44 and 48 of 27.01.2006 in the base of the argumentation that, according to the art. 17 of the Constitution, the only body entitled to issue any restrictive law in the field of human rights and liberties is the Parliament: «The expression conly by laws means that in case of restriction of any right sanctioned by the Constitution this evaluation is an exclusive discretion of the legislative power and not of other bodies, Council of Ministers included»; verbatim in Albanian language: «Shprehja "vetëm me ligj" ka kuptimin që në rast se është i nevojshëm kufizimi i një të drejte të parashikuar në Kushtetutë, atëherë ky vlerësim është në diskrecion vetëm të ligjvënësit dhe jo të organeve të tjera, përfshirë edhe Këshillin e Ministrave»). For further elaboration on Constitutional Court's jurisprudence concerning interpretations of art. 17 of the Constitution, see Court Verdict. n. 9 (2003); n. 29 (2005); n. 24 (2007); n. 39 (2007); n. 41 (2007).

37 In this sense, the Constitutional Court in a decision of 1999 (Constitutional Court of Republic of Albania, Court Verdict n. $65,10.12$. 1999) found incompatible with the Constitution the internal dispositions concerning death penalty in peace time, present either in criminal code or in the military criminal one, on the basis of the argumentation that those dispositions contrast with the Constitution (art. 21 and others) and echr (Prot. No. 6). Although, at the time, Albania had not ratified the Protocol relative to the abolition of death penalty (this Protocol was entered into force in Albania on 1 October 2000) but had temporarily suspended executions, the Constitutional judge interpreted in an extensive way the significance of art. 17, $\S 2$ of the Constitution, considering death penalty a negation, rather than a limitation, of the rights and liberties sanctioned in both instruments (Constitution and echr). 
the Court of Strasbourg, extending for example, even on the basis of the interpretation of the Albanian Constitution, some criminal and civil procedural guaranties relative to the right to a fair trial even in hypothesis of administrative cases $^{38}$. In several occasions the Court expressed its firm opposition in case of improper restriction or limitation of fundamental constitutional rights tracing a clear minimum threshold that should never be surpassed. Having to the Court been assigned the exclusive power of judge of the laws, even with reference to the Strasbourg's jurisprudence, it has repeatedly sanctioned that any indirect restriction of the right in object (right to a fair trial) provides sufficient evidence in order to censure prejudicial laws or conducts ${ }^{39}$.

A further important element in the institutional geography of the constitutional bodies involved in the human rights question within the Albanian legal order is certainly represented by the figure of the Ombudsman, or People's Advocate ${ }^{40}$. The political independence and impartiality, deducible even by the qualified quorum (3/5 of the members of the Parliament) requested for its election, combined with the constitutional guaranties granted for carrying out proper functions render this institution an important factor in the achievement of human rights standards ${ }^{41}$. Though its competencies are circumscribed to issue recommendations towards institutions considered guilty for human rights violations, its legal capacity to solicit the intervention of the Constitutional Court [art. 134, § (f)] render it an active and effective institution in defense of human rights ${ }^{42}$.

Nor could be ignored in this occasion the undisputable contribution given by the Court of Strasbourg thanks to its decisions in favor of the human rights cause, especially for what regards cases concerning Albania ${ }^{43}$. The Court's jurisprudence is considered an essential point of reference for all the national judges within European continent while for what regards cases involving Albania, its decisions have contributed considerably to the improvement of the exact application of human rights dispositions.

The attention of the Court of Strasbourg, for what concerns cases relative to Albania, has been concentrated mostly, but not exclusively, on art. 6 of echr (the right to a fair trial). Aiming to give an as more as possible extensive interpretation of the right in object, the Court never lost the opportunity to firmly underline the importance of the substantial elements of the right to a fair trial; for example, in several occasions, the Court has affirmed with force that, according to art. 6 , the «execution of a judgment given by any court must therefore be regarded as an integral part of the

\footnotetext{
${ }^{38}$ Emblematic, but not solitary, the position of the Court in the Case Rakipi v. Parliament, Court Verdict n. 76, 25.04.2002, as it censored the conduct of the Parliament which had removed from office the General Procurator of the Republic without conceding him the possibility to defend himself from charges addressed by the Parliament, underlining in this sense the violation of the right to a fair trial, though of administrative nature; verbatim, in Albanian language: "Gjykata Kushtetuese ka parasysh edhe dallimin që ekziston ndërmjet nenit 6 të Konventës Europiane për të Drejtat e Njeriut dhe nenit 42/1 të Kushtetutës të Republikës së Shqipërisë. Ndërsa në Konventë parashikohet e drejta e individit për një gjykim të drejtë penal apo civil, në nenin 42/1 të Kushtetutës dhe në jurisprudencën tashmë të konsoliduar të Gjykatës Kushtetuese, e drejta e individit për një proces të rregullt ligjor nuk është e kufizuar vetëm në procesin gjyqësor, por edhe në atë me karakter disiplinor administrativ, siç është rasti në shqyrtim». See also Court Verdict n. 75, 19.04.2002.

${ }^{39}$ The Court, though being essentially a judge of the laws, on the basis of proper competencies (art. 131 of the Const.) set strict limits with concern to individual's right to a fair trial creating the basis of a correct interpretation and comprehension of this right among all judicial operators. So, in Court Verdict n. 48 (1999); n. 15 (2000); n. 20 e 38 (2000); n. 3 e 4 (2001); n. 9 (2001); $n .17$ (2001); n. 24 e 205 (2001); n. 25 (2002); n. 76 (2002); n. 109 (2002) the Court brought out and underlined the inviolability of those individual's rights whose restriction or/and denial could deprive from all meanings the right to a fair trial itself. Consider that the violation of art. 6 of ECHR occupies the top rank ( $45 \%$ of the total) among all the violations registered by the Strasbourg's Court.

${ }^{40}$ Art. 60 to 63 of the Constitution discipline the powers and functions of the People's Advocate. He is elected by the Parliament by qualified majority for a renewable period of 5 years and constitutes an independent institution invested with the task of protecting human rights and citizen's interests from the abusive power of the public administration. Annually draws up a detailed report on the situation of human rights subject to the attention of the Parliament. If needed issues recommendations and advisory opinions relative to invested questions.

${ }^{41}$ Apart the constitutional dictate, the competencies and powers of the People's Advocate are defined in details by the Law No. 8454 of 04/02/1999 "On the People's Advocate». Though not being invested with executive or decisional powers this institution has the right to make recommendations of legislative nature addressed to the Parliament (or of administrative nature addressed to the respective institutions) aiming the improvement of the legislation in the field of human rights. For what regards the sub-legislative acts considered in violation of human rights and liberties, the silence of the competent institution for more than thirty days from the People's Advocate solicit implies the suspension and non-applicability of the same act (art. 24 of the Law No. 8454).

42 In its decisions Court Verdict n. 26 of 26/04/2001 and n. 4 of 17/02/2003 the Constitutional Court, fully accepting the People's Advocate petition invalidated as unconstitutional, in both occasions, the normative acts issued by the government.

${ }^{43}$ Albania has been arraigned before Strasbourg's Court thirty-two times and has been found guilty exactly 27 times mostly for violation of art. 6, art. 8, art. 13, art. 46 and art. 1, Prot. I.
} 
"trial" for the purposes of Article 6»44. In concrete terms, in the cases Qufaj Co. Sh.p.k. v. Albania (2004) and Balliu v. Albania (2005), the «judge of Strasbourg», referring to consolidated jurisprudence, underlined that art. 6 of the Rome Convention does not concern only the right to a fair trial in the strict sense, but rather a set of minimal guaranties aiming an «effective remedy for an alleged breach of the requirement under Article 6 of the Convention» 45 .

In other occasions, the Court of Strasbourg certified infringement of several rights and liberties sanctioned in the echr: in particular right to life (art. 2), prohibition of inhuman and degrading treatment (art. 3), right to liberty and security (art. 5), nulla poena sine lege (art. 7), right to respect for private and family life (art. 8), right to effective remedy (art. 13), right to private property (art. 1, Prot. 1) etc..

In absence of any jurisprudential tradition in the field of human rights because of the non-importance of these during the communist regime as well as the inexistence of a Constitutional Court, the long and precious experience of the Court of Strasbourg offers a unique occasion to the Albanian constitutional (but even ordinary) judge in order to introduce in the domestic law standards already accepted at European level rendering effective, in the same time, those fundamental rights and liberties sanctioned in the Constitution and the laws of the country.

For what regards, instead, the operation and the contribution of the non-governmental organizations (NGOS) in defense of human rights, there should be mentioned, ex multis, Komiteti Shqiptar i Helsinkit (Albanian Helsinki Committee - AHC), Fondacioni Shqiptar per Shoqerine Civile (Albanian Civil Society Foundation - ACSF), Grupi Shqiptar per te Drejtat e Njeriut (Albanian Human Rights Group - AHRG), Qendra Shqiptare per te Drejtat e Njeriut (Albanian Center for Human Rights - ACHR), Instituti Shqiptar i Medias (Albanian Media Institute - AMI), Forumi i Pavarur i Gruas Shqiptare (Albanian Independent Women Forum - AIWF) etc ${ }^{46}$. The lack of a civil society during almost fifty years of communism rendered too difficult the task of these NGOs in the new democratic dimension of the society ${ }^{47}$. This inexistence of civic responsibility tradition has been further on worsened by the unavailability of the ruling class to consider both NGOs and trade associations as direct interlocutors for the definition of the policy-making, inasmuch as representatives of the interests of society ${ }^{48}$. In consequence, the civic conscience of the Albanian society still remains fragile, thanks also to the strong political hostility and polarization that reigns in the Country which has brought sometimes, even to the politicization

${ }^{44}$ With regard to art. 6 see Case of Marini v. Albania, 18.12.2007; Case of Driza v. Albania and Ramadhi and Others v. Albania 13.11.2007; Case of Xheraj v. Albania 29.07.2008; Case of Dauti v. Albania, 03.02.2009; Case of Behrami v. Albania, 27.05.2010.

${ }^{45}$ "The Court reiterates that Article $6 \oint 1$ secures to everyone the right to have any claim relating to his civil rights and obligations brought before a court or tribunal; in this way it embodies the "right to a court", of which the right of access, that is the right to institute proceedings before courts in civil matters, constitutes one aspect. However, that right would be illusory if a Contracting State's domestic legal system allowed a final, binding judicial decision to remain inoperative to the detriment of one party. It would be inconceivable that Article $6 \S 1$ should describe in detail procedural guarantees afforded to litigants - proceedings that are fair, public and expeditious without protecting the implementation of judicial decisions; to construe Article 6 as being concerned exclusively with access to a court and the conduct of proceedings would be likely to lead to situations incompatible with the principle of the rule of law which the Contracting States undertook to respect when they ratified the Convention. Execution of a judgment given by any court must therefore be regarded as an integral part of the "trial" for the purposes of Article 6. It is not open to a State authority to cite lack of funds as an excuse for not honouring a judgment debt» (Case of Qufaj Co. Sh.p.k. v. Albania, 18.11.2004, § 38).

${ }^{46}$ «The overall goal of these organizations has been and continues to be the promotion of civil society by encouraging citizens to assist in three basic ways: to get along with each other, to show an interest in fulfilling their responsibility in influencing politicians and government officials to serve the common good, and to take responsibility for directly contributing to the common good through voluntary and independent civic engagement. The focus of each NGO is narrow, but when all of them are considered together, they constitute a significant force in pressuring elected officials to work for the benefit of the people. NGOs are funded by a variety of sources, but most of them get their financial support from outside the country», (Kaltsounis, The Democratization of Albania. Democracy from Within, New York, 2010, p. 93).

${ }^{47}$ «Albania did not inherit a 'civil society', because there was no separation between the state and society during the communist period, as the state and the communist party had absolute control and penetrated every aspect of society and life. Even before that, Albania lacked civic traditions and independent social organizations and associations. These historical and communist legacies have been and still are among the major obstacles to the construction of a powerful civil society in Albania», (Bogdani-Loughlin, Albania., cit. p. 187).

48 «The political elite has neither encouraged, nor has been willing to accept the contribution from civil society. Another barrier has been its lack of real autonomy from the state and especially the political parties. NGOs, think-tanks and different associations and organizations are often not free from and are usually very dependent on political influence or control. Therefore, civil society has not yet become the source of alternative views and approaches to the challenges Albania faces and which could greatly influence the decisionmakers [...] Unlike the industrialized countries where the role of the social partners is crucial and where they actively participate in policymaking (especially economic and labor policies), corporatism in Albania is almost non-existent. Trade unions are weak organizationally and have limited affiliations as a result of de-industrialization and high unemployment» (Ibid., p. 187). 
of considerable part of civic elite exponents ${ }^{49}$; this obviously generated loss of trust on public opinion towards them ${ }^{50}$.

\section{Conclusive Remarks}

In a country as Albania, where the indelible legacy of the disastrous experience of the past communist regime still threatens the progress of the rising democracy, the human rights question remains an open challenge. The actual situation in the country shows that steps forward have been made but there is still a lot to do51.

It is not a challenge against; it's a challenge for the guarantee of human rights and liberties, for the construction of a society that gives voice to the interests and requirements of its members, that creates the necessary conditions in order that these rights and liberties become a common good at the service of proper citizens. We think there is no example to follow or emulate with fanaticism; the capacity of a well-governed society is expressed exactly in its ability to translate in concrete dispositions and actions the necessities for justice and liberty coming from the social base, in full respect of its history, culture and its best traditions.

\footnotetext{
${ }^{49}$ "Albania's civil society sector remains weak and struggles to find space for meaningful activity in a highly politicized environment. Even civic activists appear to view running for office as the only real way to influence policymaking; a large number of them competed in local elections in 2011, especially in elections to municipal councils. Workers' unions in Albania remain weak due to the presence of a large informal economy and the fact that very few large companies operate in the country. Albania's civil society rating remains at 3.00» (Freedom House, Nations in Transit, 2012. Albania, p. 49).

50 «Public trust in nongovernmental organizations (NGOs) is low and state as well as non-state actors often use them as scapegoats for various problems. [...]In 2011, a number of civil society activists ran as party- or coalition-affiliated candidates in local elections, mostly for positions on municipal councils. While this situation narrows the already thin line between civic and political engagement, it is still viewed as the most effective way for civil society to influence policymaking at either the local or central level» (Ibid., pp. 55-56).

51 «There has been partial progress on addressing the key priority on reinforcing the protection of human rights and the effective implementation of anti-discrimination policies. There have been important developments in this area, in particular the adoption of the Law on Protection of the Rights of the Child, the adoption of the new National Strategy on Gender Equality and the Fight against Domestic Violence, and the start of implementation of the Law on Protection from Discrimination. However, some important legislative gaps remain, including as regards persons with disabilities, and implementation of existing legislative and policy tools in this field is still inadequate. General awareness of the anti-discrimination legislation and the complaints mechanism needs to be increased. Concerns remain over continued discrimination against certain vulnerable groups, such as LGBT persons and Roma. Implementation of policy tools targeting the Roma minority and access of this community to social protection and services is still insufficient, leading to persistent marginalization» (European Commission, Albania 2011 Progress Report, pp. 17-18).
} 